\title{
Evaluation of green waste composting possibilities
}

\author{
Irina Kliopova, Kamilė Stanevičiūtė \\ Kaunas University of Technology, Institute of Environmental Engineering \\ crosgref $\mathrm{http} / / / \mathrm{dx}$. doi.org/10.5755/j01.erem.63.3.4680
}

(Received in June, 2013; accepted in September, 2013)

In Lithuania main part of biodegradable waste (BDW) from the municipal waste (MW) stream, food waste from coffees and other catering companies are disposed of in landfills. Primary BDW sorting and / or secondary processing within the mechanical-biological treatment (MBT) equipment is planned in Waste Management Plants (WMP) in all Lithuanian regions. Lithuania has old traditions of BDW management methods, as green waste (GW) composting e.g. mulching is one of the most popular, especially in rural areas. Therefore, reinstatement of composting traditions by implementing modern composters (composting bins) in the territories of individual households is practically provided by all WMP. Composting of sorted BDW from MW stream and $\mathrm{GW}$ from public territories or green areas of companies is one of the useful BDW management methods, because, first of all, a new product - bio-compost is produced and used for agricultural purposes.

This paper presents results of the research done in the Institute of Environmental Engineering (APINI) of Kaunas Technological University (KTU) implementing two projects: Home composting in individual households of Taurage region (RECO Baltic 21 Tech (RB21T) project) and Feasibility analysis of BDW management techniques in KTU ("KTU - Green University" project). This research work focuses on the green waste (garden and green food waste) composting possibilities.

Key words: biodegradable waste, green waste, home-composting, composting bin, compost quality indicators, probiotics, feasibility analysis, material and energy balance, Green University.

\section{Introduction}

A significant point of the issues related to biodegradable waste (BDW) management is disposal of this waste in landfills. Approx. 1.2 - 1.3 millions t of municipal waste (MW) (unvalued green waste (GW) from public territories) is annually generated in Lithuania (Index data base 2013). BDW makes up 45$55 \%$ of the total MW stream. In 2011, $77 \%$ of the collected MW was disposed in landfills, only $2 \%$ of BDW from the MW stream was composted. Actually, the amount of GW composted in rural districts was not evaluated in these indicators (Environmental Agency 2013).

Several GW composting sites still exist from the past, but they are not technically equipped in accordance with the rules of industrial composting (no impermeable covering, no storm water collection system, etc).

Decomposition of BDW has a significant impact on climate change. BDW management has to be one of the priority actions related to waste management.

Since 2010, Lithuania takes an active part in planning BDW separation from the other MW stream. According to the Lithuanian National Strategic Waste Management Plan, the amount of disposed BDW by 2020 can make no more than $35 \%$ compared to the amount of BDW in 2000 (National Strategic Waste Management Plan 2010).

The National Strategic Waste Management Plan emphasizes that "green waste" from gardens, green areas and parks must be collected and treated in composting systems. In addition, the individual home- 
composting of green waste is to be promoted (National Strategic Waste Management Plan 2010).

Given the fact that all regions have to ensure the BDW management (mechanical biological treatment (MBT) of MW or primary sorting of BDW from MW stream and treatment), all Lithuanian Regional Waste Management Centers (RWMC) have prepared feasibility studies on BDW management.

This paper focuses on the GW composting, which is one of the most environmentally friendly and economically useful techniques of BDW management. Home-composting of $\mathrm{GW}$ is provided in all Lithuanian regions.

This article presents in detail the information on results of the two projects ongoing in the Institute of Environmental Engineering (APINI), Kaunas Technological University (KTU):

- home - composting in individual households of Tauragè region (RECO Baltic 21 Tech (RB21T) project) (Feasibility study, Part I 2012; Feasibility study, Part II 2013);

- feasibility analysis of BDW management techniques in Kaunas University of Technology ('KTU - Green University" project) (Stanevičiūtė 2013).

\section{Main parameters of BDW composting process and quality indicators of produced compost}

Composting is aerobic processing of BDW when waste mineralizes due to the complex biological, biochemical, and physical processes, biogenic elements get free, and humus is formed. The same processes take place in soil, but many times faster and more efficiently. Therefore, mature compost is not only a valuable fertilizer, but also a kind of stimulus for soil vitality.

Primary objectives of BDW composting are the following:

- to convert BDW into a biologically stable product;

- $\quad$ to reduce the volume of organic waste going to landfills;

- to destroy pathogens or unwanted microorganisms;

- to retain the nutrient content of the original waste (nitrogen, phosphorus, potassium, etc);

- $\quad$ to make a product that can support plant growth and improve the soil structure.

Main parameters of the composting process are:

- temperature (the process takes place due to temperature changes): from 15 to $75{ }^{\circ} \mathrm{C}$;

- moisture content (optimal volume: $50-60 \%$ );

- oxygen content (optimal volume: 15-20\%);

- C:N ration (optimal volume: 20-30:1);

- $\quad$ pH (optimal volume: 6-8);

- biochemical composition and structure.

In 2012 researchers of the Agrochemical Research Laboratory of the Center of Lithuanian Agriculture and Forestry Science (LAAMMC) suggested ranking some quality indicators of produced compost as a fertilizer in their applied research work "Analysis and evaluation of quality requirements of compost usable for agriculture".

Input flows:

Output flows:

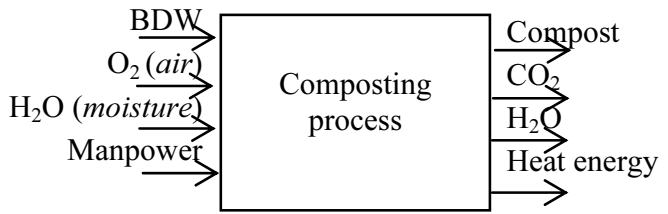

Fig. 1. Flow chart of classic composting process

The value of compost is divided into very low, low, medium, high, very high (Staugaitis et al. 2012). The part of recommended quality indicators and the range of valuable compost are presented in Table 1.

Table 1. Compost quality indicators and their limits (Staugaitis at al. 2012)

\begin{tabular}{|c|c|}
\hline $\begin{array}{c}\text { Compost quality as a fertilizer } \\
\text { indicators }\end{array}$ & VCQIL \\
\hline $\mathrm{pH}_{\mathrm{KCl}}$ & $5.6->8.5$ \\
\hline Dry material, $\%$ & $21->50$ \\
\hline Organic materials, $\%(d)$ & $16->45$ \\
\hline Total nitrogen $(\mathrm{N}), \%(\mathrm{~d})$ & $0.5->2.0$ \\
\hline Total phosphorus $(\mathrm{P}), \%(\mathrm{~d})$ & $0.21->0.8$ \\
\hline Total kalium $(\mathrm{K}), \%(\mathrm{~d})$ & $0.6->2.5$ \\
\hline Electrical conductivity, $\mathrm{mS} / \mathrm{cm}$ (ar) & $0.6->2$ \\
\hline $\begin{array}{l}\text { Water-soluble nitrogen and /or mineral } \\
\text { nitrogen }\left(\mathrm{N}-\mathrm{NH}_{4}+\mathrm{N}-\mathrm{NO}_{3}\right), \mathrm{mg} / \mathrm{l} \text { (ar) }\end{array}$ & $51->200$ \\
\hline Water-soluble phosphorus (P), mg/l (ar) & $26->100$ \\
\hline Water-soluble kalium (K), mg/l (ar) & $91->300$ \\
\hline $\mathrm{C}: \mathrm{N}$ ration, (ar) & $11->25$ \\
\hline Cadmium $(\mathrm{Cd}), \mathrm{mg} / \mathrm{l}(\mathrm{d})$ & $\leq 30-\leq 7$ \\
\hline Lead $(\mathrm{Pb}), \mathrm{mg} / \mathrm{l}(\mathrm{d})$ & $\leq 180-\leq 45$ \\
\hline Mercury $(\mathrm{Hg}), \mathrm{mg} / \mathrm{l}(\mathrm{d})$ & $\leq 2-\leq 0,4$ \\
\hline Chromium (Cr), mg/l (d) & $\leq 120-\leq 70$ \\
\hline $\operatorname{Zinc}(\mathrm{Zn}), \mathrm{mg} / \mathrm{l}(\mathrm{d})$ & $\leq 6000-\leq 200$ \\
\hline Copper $(\mathrm{Cu}), \mathrm{mg} / \mathrm{l}(\mathrm{d})$ & $\leq 300-\leq 70$ \\
\hline $\operatorname{Nickel}(\mathrm{Ni}), \mathrm{mg} / \mathrm{l}(\mathrm{d})$ & $\leq 60-\leq 25$ \\
\hline $\operatorname{Arsenic}(\mathrm{As}), \mathrm{mg} / \mathrm{l}(\mathrm{d})$ & $\leq 25-\leq 10$ \\
\hline $\begin{array}{l}\text { Escherichia coli (E.coli), colon. } \\
\text { units } / \mathrm{kg}\end{array}$ & $\leq 1000$ \\
\hline Clostridium perfringens, colon. units/g & $\leq 100000$ \\
\hline Helminth eggs and larvae, units $/ \mathrm{kg}$ & 0 \\
\hline Salmonella bacteria, units/g & 0 \\
\hline
\end{tabular}

\section{Comments:}

$d$-in dry matter;

ar-as received;

VCQIL - limits of quality indicators of valuable compost:

$<$ First value - very low value (in case of heavy metals - III category of compost used for land remediation);

$>$ Second value - very high (in case of heavy metals - I category of compost used in agriculture).

\section{Possibilities of managing BDW received from MW stream}

Widely used management techniques of BDW received from $\mathrm{MW}$ are:

- primary separation of BDW and its transfer to waste managers - users (different separation methods are applied, depending on the collection 
system: separate containers, bags of different colors, etc);

- home-composting of GW, inc. that from food waste stream, using the produced compost for their own purposes (see Paragraph 4);

- primary separation of BDW, industrial composting and usage of produced bio-compost therein and / or for sale (see Paragraph 5);

- secondary separation of BDW fraction of MW and processing within MBT (Mechanical and Biological Treatment) equipment:

○ open composting (aerobic processing): with forced air supply, without forced air supply (using turners);

- closed composting (aerobic processing): using cover systems, tunnel system, containers system;

o anaerobic treatment, energy extraction: wet or dry fermentation (this method is not analyzed in this paper).

\section{Aerated Windrow Cover System}

To ensure a proper composting process, all technological parameters are to be maintained (see Paragraph 2). A special film made of LDPE (LowDensity Polyethylene), or goretex material, etc is used for maintaining the proper moisture and temperature within a pile during the composting process. Being waterproof and windproof the cover material protects the composting material from the elements and also from unwelcome decaying processes. At the same time, the cover works as a physical barrier against odors and other gaseous substances escaping from the composting material. For example, GORETM Cover System, compared to composting in open windrows without aeration control, can achieve a reduction in odor concentrations of up to $97 \%$ without additional filtering installations (GORETM Cover System).

Duration of the first stage of the composting process (production of "raw" compost) using this composting system is up to 6 weeks (up to 8-9 cycles per year). Waste water (filtrate) and rainwater drainage and treatment system must be implemented in this stage of composting.

The second composting stage is maturation of "raw" compost and continues for approx. 3-4 weeks.

\section{Intensive composting in tunnel and/ or container system}

Using this in-vessel technology, composting process goes on in tunnels or containers. A first stage of the composting process (intensive composting) in tunnel lasts 3-4 weeks (up to 12-17 cycles/year), in container - up to 3 weeks (up to 17 cycles/year). One system consists of a few composting tunnels or containers. Their number depends on the capacity (size) of one tunnel (container), and the amount and composition of BDW.

In case a container system is used, air filtration and pipe systems are installed in the container.
Besides, this system is mobile and can be quite easily transported to other territories. The bottom of each container is equipped with a waste water drainage system.

In such systems the air flow is fully controlled and makes it possible to maintain proper moisture and temperature of the aeration process.

After an intensive composting process additional stabilization of BDW is required i.e. maturation in a separate site for 3-4 weeks.

In the whole composting process about $50 \%$ of BDW weight is lost, $40 \%$ of which is due to moisture evaporation and about $10 \%$ is due to biodegradation of dry material.

Main advantages of intensive composting technologies compared to open composting are: higher control of composting parameters; compost is produced in the shortest period of time; the least stretch of land is occupied; odor and gas emissions into the air are minimal (Smith et al. 2011).

Main disadvantages of this composting technique are: most capital intensive; extensive training of personnel; higher maintenance and operational costs (Ripley et al. 2008).

Comparing different processing techniques of BDW received from MW stream, it should be noted that:

- $\quad$ primary sorting of BDW will make it possible to produce bio-gas and bio-compost;

- $\quad$ efficiency of primary sorting of BDW depends on sorting and collection options;

- home composting of GW (from garden and food waste stream) should be popularized, for example, to use composting containers, particularly within the towns, in which individual households dominate;

- $\quad$ to eliminate the odor, to improve the quality of composting process probioticts (e.g. SCD Odor Away) can be used (AVAI; Feasibility study, Part I 2012);

- the amount and preliminary composition of MW flow has to be evaluated with a view to increasing productivity and efficiency of the MBT equipment;

- anaerobic dry fermentation of BDW is technically feasible and economically profitable when over 20 thousand t/y of waste are treated;

- intensive composting in a tunnel system is chosen when over 5 thousand $\mathrm{t} / \mathrm{y}$ of BDW are processed;

- when choosing an open composting system, it is better to use a cover layer system (for example, goretex), which helps ensure that the thermophilic temperature is reached and emissions into the air are reduced;

- $\quad$ in resort towns with plenty of canteens, cafés, and other catering institutions, in which considerable amount of food waste is produced, it is worth promoting a separate food waste collection and composting (Kliopova 2012) and:

- to use Jorakompost or other similar devices in those institutions; 
- to transport BDW to the MBT for bio-compost production.

\section{Results of home-composting in Tauragè region}

Home-composting is composting of BDW obtained in individual households and producing biocompost for use therein. In case of BDW collecting from the neighboring territories and composting together with their own BDW, the requirements for industrial composting are applied to such composting process.

There are no special requirements for homecomposting. It is advisable to follow the recommendations, particularly in reaching thermophilic temperatures $\left(50-70^{\circ} \mathrm{C}\right)$, because the compost produced that way does not pose any pathogenic, phytopathogenic and plant-health risks, and does not spread a variety of weed seeds.

Home-composting is a good possibility for individual holdings to produce bio-compost from BDW, to save costs for fertilizer purchase, to minimize MW disposal in landfills and to reduce MW management costs. Home-composted BDW is listed in Table 2.

The overall objective of the RECO Baltic 21 Tech Project (RB21T) is to improve the local and regional capacity in the area of integrated waste management, to apply the process of implementing waste management that supports the implementation of the waste-related EU Directives and enables the region to climb in the waste hierarchy (RECO Baltic 21).

One of the RB21T tasks in Lithuania is to prepare a feasibility study of BDW management in individual households of Taurage region. The target of this feasibility study is practical and theoretical assessment of possibilities to compost green waste obtained in individual households (see Table 2).

Table 2. Home-composted BDW from MW stream

\begin{tabular}{|c|c|}
\hline Municipal waste & Garden waste \\
\hline $\begin{array}{ll}- & \text { fruit and vegetable waste; } \\
- & \text { egg shells; } \\
- & \text { tea and coffee grounds; } \\
- & \text { wood ashes and coal (in } \\
& \text { small quantities); } \\
- & \text { cardboard and other } \\
& \text { paper products without a } \\
& \text { press (tear up); } \\
- & \text { small pets (hamsters, } \\
& \text { guinea pigs) natural litter }\end{array}$ & $\begin{array}{l}\text { - leaves; } \\
\text { - cut the grass; } \\
\text { - } \text { small branches; } \\
\text { - weeds without mature } \\
\text { seeds; } \\
\text { - old straw, hay, turf; } \\
\text { - } \text { rabbit, chicken, } \\
\text { horse, cow manure }\end{array}$ \\
\hline \multicolumn{2}{|c|}{ Non-composted BDW: } \\
\hline \multicolumn{2}{|c|}{$\begin{array}{l}\text { raw meat, fish; fat, bones; dairy products; cooked } \\
\text { vegetables; sick plants, weeds with mature seeds; } \\
\text { newspapers, magazines; dog, cat feces, pig manure }\end{array}$} \\
\hline
\end{tabular}

Taurage region encompasses 7 towns (Tauragè, Jurbarkas, Šilalè, Pagegiai, Skaudvilè, Smalininkai, Panemunè), 20 small towns, and approx. 1233 villages. Approx. 121 thousand people live in this Lithuanian region, inc. $41 \%$ of urban population, the other are rural people. More than $55 \%$ of all flats within this region are individual households, inc. up to
$35 \%$ of them in towns, up to $75 \%$ in small towns and villages (Feasibility study, Part I 2012).

About 30 thousand $t / y$ of $\mathrm{MW}$ are produced in Taurage region, inc. $50-60 \%$ of BDW (15-18 thousand $\mathrm{t} / \mathrm{y}$.). Only $5600 \mathrm{t} / \mathrm{y}$. of BDW can be disposed of in landfills (35\% of $2000 \mathrm{y}$. level) (National Strategic Waste Management Plan 2010). Hereby, the BDW processing techniques with the total capacity of 9.412.4 thousand $\mathrm{t} / \mathrm{y}$ must be implemented in Taurage region during this period.

The Taurage region waste management plan (for 2010-2020) and the BDW management feasibility study focus on the primary BDW separation, GW composting in individual household, inc. towns and small towns (Feasibility Study on Biodegradable Waste 2010; Waste Management Plan 2010). In accordance with the theoretical evaluation, $2.15-4.3$ thousand $\mathrm{t} / \mathrm{y}$ of GW from municipal waste stream will be composted $(300-500 \mathrm{~kg} / \mathrm{y}$. for 1 household $)$ (Feasibility Study on Biodegradable Waste 2010).

Main results of the feasibility study of BDW management in individual households of Taurage region are further discussed in the paper:

- conditions of the composting process are evaluated, and recommendations for their achievement are presented in Table 3;

- suggested composting bins (containers) are compared, their advantages and weaknesses are estimated;

- criteria for selection of composting containers are presented (see Table 4);

- BDW home-composting experiment was carried out during the summer of 2012 for both the evaluation of different technical, climate and other conditions having an impact on the composting process and the preparation of recommendations for composting (Feasibility study, Part II 2013).

Commonly used composting bins (Feasibility study, Part I 2012) are:

- $\quad$ open bins $\left(\mathrm{V}>1 \mathrm{~m}^{3}\right)$ : more suitable for garden GW composting; the composting period under Lithuanian conditions is up to 2 years;

- closed bins (V: $\left.0.3-1.2 \mathrm{~m}^{3}\right)$ : diversiform, sizes, design decisions; some of them improved, for example, with a stirrer system, or with 2 or 3 chambers $\quad\left(1^{\text {st }}-\right.$ for BDW stir, $2^{\text {nd }}-$ for composting and raw compost production, $3^{\text {rd }}$ for maturation), etc;

- closed containers with additional warming (for composting all BDW from municipal waste stream);

- $\quad$ special bins for vermi-composting: composting, using various worms, usually red wigglers, to create a heterogeneous mixture of BDW.

19 individual households participated in the experiment in Taurage region with a technical assistance of the Taurage Waste Management Center, KTU APINI and "Ekobaltas" Ltd.: 10 - cities, 9 - in rural areas. 10 households composted BDW in a classical way, 9 households used SCD Odor Away probiotics. 
Table 3. Technical conditions of composting process

\begin{tabular}{|c|c|c|}
\hline $\begin{array}{l}\text { Parameters of } \\
\text { compositing } \\
\text { process }\end{array}$ & Conditions of composting process & Comments \\
\hline $\begin{array}{l}\text { Moisture } \\
\text { content }\end{array}$ & $\begin{array}{l}\text { Optimal moisture content - } 50-60 \% \text {. If moisture } \\
\text { content is less than } 40 \% \text {, the activity of } \\
\text { microorganisms decreases, in case of } 20 \% \text { it stops. } \\
\text { If moisture content is more than } 70 \% \text {, anaerobic } \\
\text { process begins. }\end{array}$ & $\begin{array}{l}\text { When BDW is not sufficiently wet, it must be } \\
\text { irrigated. When BDW is wet, it must be mixed } \\
\text { with dry waste. }\end{array}$ \\
\hline Temperature & $\begin{array}{l}\text { Raw compost production (primary composting): } \\
\circ \quad \text { psychrophilic stage }\left(15-20^{\circ} \mathrm{C}\right) \\
\circ \quad \text { mesophilic stage }\left(25-35^{\circ} \mathrm{C}\right) \\
\circ \quad \text { thermophilic stage }\left(50-75^{\circ} \mathrm{C}\right) \\
\text { Maturation and stabilization of "raw" compost } \\
\left(45-20^{\circ} \mathrm{C}\right) \text { - mineralization of organic materials. } \\
\end{array}$ & $\begin{array}{l}\text { Practically, during the summer season waste } \\
\text { decomposition by micro-organisms is much } \\
\text { more intensive and faster than in winter. In } \\
\text { winter, biochemical degradation processes } \\
\text { practically stop, when an open composting } \\
\text { method is applied. }\end{array}$ \\
\hline $\mathrm{C}: \mathrm{N}$ ration & $\begin{array}{l}\text { Composting process begins when the } \mathrm{C}: \mathrm{N} \text { ratio } 20 \text { - } \\
30: 1 \text { (optimal ratio). }\end{array}$ & $\begin{array}{l}\text { BDW must be mixed, considering the nitrogen } \\
\text { and carbon ration, for example, composting of } \\
\text { green garden or green food waste, which is } \\
\text { rich in nitrogen, this waste is mixed with tree } \\
\text { leaves, hay, straw, wood, paper and cardboard } \\
\text { waste, which are rich in carbon. }\end{array}$ \\
\hline Oxygen content & $\begin{array}{l}\text { Optimal } \mathrm{O}_{2} \text { volume: } 15-20 \% \text { of } \mathrm{BDW} \text { volume. If } \mathrm{O}_{2} \\
\text { content is less than } 10 \% \text {, the composting process } \\
\text { slows down because of anaerobic digestion. If } \mathrm{O}_{2} \\
\text { content is more than } 20 \% \text {, the composting process } \\
\text { slows down because of a decrease in the temperature } \\
\text { (thermophilic stage is unapproachable). }\end{array}$ & $\begin{array}{l}\text { Frequency of aeration depends on BDW: } \\
\text { - in case of grass composting, there is more } \\
\text { turning (because the anaerobic process } \\
\text { begins); } \\
\text { - in case of grass mixing with chopped trees } \\
\text { or leaves, as well as straw, sawdust, wood } \\
\text { chips, etc with the ratio of } 2-3: 1 \text { there should } \\
\text { be less turning. }\end{array}$ \\
\hline pH & $\begin{array}{l}\text { Initial stage of composting process: } \mathrm{pH} 6-8 \text {; } \\
\text { mesophilic stage: } \mathrm{pH} \text { decreases up to } 5 \text {; thermophilic } \\
\text { stage: } \mathrm{pH} \text { increases up to } 7-8 \text {. }\end{array}$ & $\begin{array}{l}\mathrm{pH} \text { can be adjusted with each other by mixing } \\
\mathrm{BDW} \text {, it is possible to add mineral additions. }\end{array}$ \\
\hline $\begin{array}{l}\text { Size of BDW } \\
\text { fraction }\end{array}$ & $\begin{array}{l}\text { Crush down of BDW by various methods (cutting, } \\
\text { milling, chopping or otherwise), their surface area } \\
\text { increases, nutrients become more available for } \\
\text { decomposers, but in the other case, interstices } \\
\text { between BDW decrease and the } \mathrm{O}_{2} \text { content also } \\
\text { decreases. }\end{array}$ & $\begin{array}{l}\text { Too much BSA crushing and anaerobic decay } \\
\text { may occur } \\
\text { Aerobic process will not start, if the size of } \\
\text { BDW fraction is too big. }\end{array}$ \\
\hline Size of pile & $\begin{array}{l}\text { Pile must be measurable. Maximum height: } 1.5-2 \\
\mathrm{~m} \text {. In case of a higher pile, anaerobic process begins } \\
\text { (due to minimization of } \mathrm{O}_{2} \text { content within bottom } \\
\text { courses). In case of a smaller pile, thermophilic } \\
\text { process can not begin. }\end{array}$ & $\begin{array}{l}\text { Pile height depends on BDW: its moisture } \\
\text { content, degree of crushing, initial density. }\end{array}$ \\
\hline
\end{tabular}

SCD Odor Away probiotics made of natural probiotic microorganisms (e.g. Lactobacillus Acidophillus L. Bulgaricus, L. Casie, L. Fermentum, L. Plantarum Streptococcus Thermophilus, yeast Saccharomyces cerevisiae, photosynthetic bacteria, etc) (AVAI) have the following characteristics:

- perform the functions of disinfection, but as distinct from ordinary chemicals (e.g., chlorine compounds and so on.) probiotics are non-toxic and harmless to the environment;

- completely safe for humans and animals;

- completely biodegradable.

The benefit of probiotics usage in home-composting process was evaluated during the experiment.

The equipment used in the experiment is Italian production composting bins with an innovative aeration system. Container's capacity is 700 liters, height $-0.8 \mathrm{~m}$, base diameter $-1.15 \mathrm{~m}$. Container is made of $100 \%$ of recycled HDPE.

Duration of the experiment was 3.2 months (from late May to early September). Usually, in Lithuania the composting season starts from late April to early November. Therefore, the experiment did not reveal how much it is possible to compost waste during the whole composting season.

The average temperature and humidity in the Taurage region during the analyzed period is presented Table 5 (World's weather online).

Compared to the standard climate conditions, in Lithuania, in June the rainfall exceeded multi annual average by $50 \%$, and an average air temperature was $1.4^{0} \mathrm{C}$ lower than the multi annual average, but in other months the average air temperature was $1-2^{\circ} \mathrm{C}$ higher than the multi annual average. 
Table 4. Choosing criteria for composting bin (container) (Feasibility study, Part II 2013)

\begin{tabular}{|c|c|}
\hline Criteria & Comments \\
\hline $\begin{array}{l}\text { Volume : } \\
\text { optimal: } 700-900 \\
\text { liters for } \\
\text { household with } 2- \\
5 \text { people and } 0.06 \\
\text { ha of the plot area }\end{array}$ & $\begin{array}{l}\text { In case of a less volume of composting bin (for example, }<5001 \text { ), the composting process will be } \\
\text { unwieldy: compost can freeze in winter, dry in summer, and it is difficult to achieve the proper } \\
\text { temperature (higher than } 50^{\circ} \mathrm{C} \text { ). } \\
\text { In case of a bigger volume of composting bin (for example, }>9001 \text { ), anaerobic conditions can begin. } \\
\text { The systems with several standard composting bins have to be used for larger households, or hotels, } \\
\text { etc instead of a bigger one. }\end{array}$ \\
\hline $\begin{array}{r}\text { - number of } \\
\text { people living in } \\
\text { individual house }\end{array}$ & $\begin{array}{l}\text { - the volume of generated green food waste suitable for composting depends on the number of } \\
\text { people }\end{array}$ \\
\hline - plot area & - the volume of green garden waste depends on the area of a handled site \\
\hline Height & $\begin{array}{l}\text { Commonly, the requirements for the composting bins volume are determined. The height of the } \\
\text { container is selected by the manufacturer, depending on the volume and form. }\end{array}$ \\
\hline Air supply & $\begin{array}{l}\text { The construction of composting bins must ensure the air supply to the composting bin for } \\
\text { maintaining aerobic conditions. There should be a sufficient number of holes over the surface area } \\
\text { (not just at the top and bottom of the bin). The top of the composting bin (place for waste filling) } \\
\text { must be free of holes. The optimal } \mathrm{O}_{2} \text { volume in composting bin is } 15-20 \% \text { of the composting mass } \\
\text { volume (see Table 3). }\end{array}$ \\
\hline $\begin{array}{l}\text { Open or closed } \\
\text { composting bin }\end{array}$ & $\begin{array}{l}\text { If the composting bin is used outdoors, it should be without bottom. } \\
\text { In individual holdings of rural areas, composting bin can be open (without cover), when is planned } \\
\text { to manage only green garden and green food waste. } \\
\text { In individual holdings of urban areas it is better to use closed composting contraction bins due to the } \\
\text { following reasons: aesthetic advantage, shorter composting period, minimization of risks of odor, } \\
\text { mice, rats, various flies. }\end{array}$ \\
\hline $\begin{array}{l}\text { Material: } \\
-\quad \text { wood or } \\
\quad \text { plastic (open); } \\
-\quad \text { plastic (closed) }\end{array}$ & $\begin{array}{l}\text { The material of composting bins should maintain the temperature range }\left(-40^{\circ} \mathrm{C} \text { to }+80^{0} \mathrm{C}\right) \text { and be } \\
\text { impact-resistant. It is sufficient that composting bins are made of the mix of recycled plastic, in } \\
\text { which HDPE dominates (also PE, and PET). International recycling marks are given on a } \\
\text { composting bin or on its separate parts. Composting bins made of only HDPE are significantly more } \\
\text { expensive. } \\
\text { Thickness of the walls of composting bin is } \geq 2 \mathrm{~mm} \text {. Manufacturer selects optimum thickness of the } \\
\text { wall (from } 2 \text { to } 10 \mathrm{~mm} \text { ), it depends on the sort of plastic. } \\
\text { Typically, the manufacturer performs the analysis before supplying composting bins to the market. } \\
\text { Therefore, manufacturer's declaration or product's certificate is added to the product. This document } \\
\text { states that the product is suitable for BDW composting. }\end{array}$ \\
\hline $\begin{array}{l}\text { Stability and } \\
\text { form }\end{array}$ & $\begin{array}{l}\text { There is a variety of composting bins shapes in the market: square, rectangular, hexagonal, frustum, } \\
\text { prisms, etc. Manufacturers are trying to make a form that would allow the composting box (empty, } \\
\text { partially or fully filled) to stand steadily on the base. Attention should be paid to the instructions. If } \\
\text { the instruction says that the composting bin can be used only on the level surface, it means that if the } \\
\text { surface is uneven, the composting bin may deform during usage (lose its original form). Due to } \\
\text { deformation its bottom door may be hard to open and its cover may be leaky when closed. }\end{array}$ \\
\hline $\begin{array}{l}\text { Bottom hole for } \\
\text { removal of } \\
\text { compost }\end{array}$ & $\begin{array}{l}\text { Composting bin has to be produced with closed-door (hole) for removing the produced compost. The } \\
\text { door must open easily to remove the compost and then it must close down. The manufacturer strives } \\
\text { to select such height of this hole that the produced compost may be easily removed by means of } \\
\text { forks or other garden tools. }\end{array}$ \\
\hline $\begin{array}{l}\text { Thermal } \\
\text { insulation }\end{array}$ & $\begin{array}{l}\text { Thermal insulation for composting bin is required if small quantities of such food waste as meat, } \\
\text { fish, and fats are composted, i.e. not only green garden and food waste. It is advisable that green } \\
\text { waste prevails in BDW mixture. } \\
\text { The construction of composting bins must ensure that the temperature up to } 70^{\circ} \mathrm{C} \text { would be reached } \\
\text { during the composting process. Using composting bins with thermal insulation, the composting } \\
\text { process can be done during the winter time, too. }\end{array}$ \\
\hline Color & $\begin{array}{l}\text { There is a great variety of colors of composting bins. When choosing a color, it is necessary to keep } \\
\text { in mind that non-black colored bins are more expensive. Black color absorbs more sun heat, and it is } \\
\text { an advantage for composting during the winter time. }\end{array}$ \\
\hline Standards & $\begin{array}{l}\text { There are no standards of composting bins. } \\
\text { The environmental management systems of companies - manufacturers can be certified to the ISO } \\
14001 \text { international standard, which ensures that pollution prevention methods were applied during } \\
\text { the production. } \\
\text { The product certificate or manufacturer's declaration must be supplied with the composting bin to } \\
\text { warrant that the product is produced for BDW composting (i.e. aerobic treatment). }\end{array}$ \\
\hline
\end{tabular}


Table 5. Air conditions in Taurage region during homecomposting experiment

\begin{tabular}{|l|c|c|c||}
\hline Period & $\begin{array}{l}\text { Average } \\
\text { temperature } \\
\text { (day), }{ }^{0} \mathrm{C}\end{array}$ & $\begin{array}{l}\text { Average } \\
\text { temperature } \\
\text { (at night), } \\
{ }^{0} \mathrm{C}\end{array}$ & $\begin{array}{l}\text { Precipitation } \\
\text { (average } \\
\text { volume), } \\
\text { mm }\end{array}$ \\
\hline $\begin{array}{l}14.05 .2012 . \\
31.05 .2012\end{array}$ & 18.9 & 7.5 & 2.12 \\
\hline $\begin{array}{l}01.06 .2012 \\
30.06 .2012\end{array}$ & 19.5 & 8.6 & 3.81 \\
\hline $\begin{array}{l}01.07 .2012 \\
31.07 .2012\end{array}$ & 24.4 & 13.10 & 2.98 \\
\hline $\begin{array}{l}01.08 .2012 \\
31.08 .212\end{array}$ & 22.2 & 11.8 & 2.75 \\
\hline $\begin{array}{l}01.09 .2012 \\
15.09 .2012\end{array}$ & 19.1 & 10.7 & 2.9 \\
\hline
\end{tabular}

The results obtained during the experiment (Feasibility study, Part II 2013):

- Density of grass and other garden weeding waste with $40-50 \%$ of moisture content is estimated from 400 to $450 \mathrm{~kg} / \mathrm{m}^{3}$. That meets the results of the literature analysis: $200-270 \mathrm{~kg}$ of dry matter per $\mathrm{m}^{3}$ (Špokas 2009).

- The relation between the amount of cumulative GW (grass, weeding waste, dried flowers, straw) and the plot area is determined on average $31 \mathrm{~kg}$ /are (from 11 to $88 \mathrm{~kg} /$ are).

- The amount of collected garden GW depends on the location (urban or rural), variety of plants, which are grown in this plot. A bigger amount of $\mathrm{GW}$ is collected in a household with green lawns and growing vegetables.

- The amount of GW from food waste stream during the experiment period was evaluated on average as $10 \mathrm{~kg} /$ person or approx. 3 $\mathrm{kg} /$ person/month $(5-35 \mathrm{~kg} /$ person).

- It is evaluated that in a composting bin with a volume of 700 liters the following amount of GW was composted during experiment period.

- On average $331 \mathrm{~kg}$ for one household (873 liters/1 household) $\quad$ or approx. $\quad 95 \quad \mathrm{~kg} / \mathrm{l}$ household/month:

○ in rural areas, on average $367 \mathrm{~kg} / 1$ household or $105 \mathrm{~kg} / \mathrm{l}$ household/month;

0 in towns and small towns areas, on average $310 \mathrm{~kg} / 1$ household or $88.5 \mathrm{~kg} / \mathrm{l}$ household/month.

- The maximum amount of GW composted during the analyzed period is estimated as $691 \mathrm{~kg}$ or 1685 liters for one household ( 2 persons, 0.06 ha of plot area).

- The minimum amount of GW composted during the analyzed period is estimated as $182 \mathrm{~kg}$ or 490 liters for one household ( 2 persons, 0.1 ha of plot area).

- The volume of composted GW was reduced by 1.3 - 2.4 times during the experiment period.

- It should be noted that the amount of GW over the whole composting period in Lithuania should increase to $400-450 \mathrm{~kg}$ (as received)/ 1 household / 1 season (the quantity presented in the literature is about $500 \mathrm{~kg} / 1$ household / 1 season), and our experiment was completed at the beginning of autumn (before leaf collection and vegetable waste generation period).

Disturbances of the composting process and their compensation are evaluated as:

0 the air temperature and humidity (disturbances are compensated by a composting bin);

- mistakes during the composting process (see Conclusions) (disturbances are compensated by different media techniques).

To improve the composting process the following additional materials are suggested:

- Probiotic substances - 1 liter for one household during the composting season $(0.1$ liter of probiotic composition is diluted with 10 liters of water; this amount should be consumed for wetting of $100 \mathrm{~kg}$ of BDW; spray is used for watering);

- sawdust and/or ash can be used in traditional composting process (about 10-15 liters during the composting period); it improves the $\mathrm{C}: \mathrm{N}$ ratio, especially if only grass and / or food green waste is mainly composted;

- the previous year compost is used in traditional composting process (about $10 \mathrm{~cm}$ at the bottom of a composting bin); old compost will improve the reproduction of micro-organisms.

An impact of SCD Odor Away probiotics compositions on the composting process is evaluated:

$\checkmark$ the duration of the whole composting process is minimized because of decline in the mesophilic composting phase;

- the risk of unpleasant odor and flies rise is decreased;

0 in case of a proper use of probiotics (in accordance with the recommendations), in Lithuania, bio-compost can be produced within 3 - 3.5 months, a full composting process can be completed within one season; an autumn compost can be produced.

\section{Feasibility analysis of BDW management techniques in Kaunas University of Technology}

One of the objectives of Kaunas University of Technology (KTU) is to become Green University. In this respect it may be said that an inconsiderable attention is paid to the KTU waste management, inc. BDW.

Among other environmental activities, in 2012 the Institute of Environmental Engineering (APINI) started to implement a waste management project in KTU: its $1^{\text {st }}$ step - primary sorting of secondary raw materials (paper and cardboard waste and packaging, plastic waste and packaging, glass waste and packaging) from MW stream, the $2^{\text {nd }}$ step - sorting of hazardous waste from MW stream. 
Feasibility analysis of the BDW management techniques in KTU is the $3^{\text {rd }}$ step in continuing waste management (Stanevičiūtè 2013).
KTU-owned green areas, canteens and a café are the main BDW sources in the university (unvalued paper and cardboard waste and packaging).

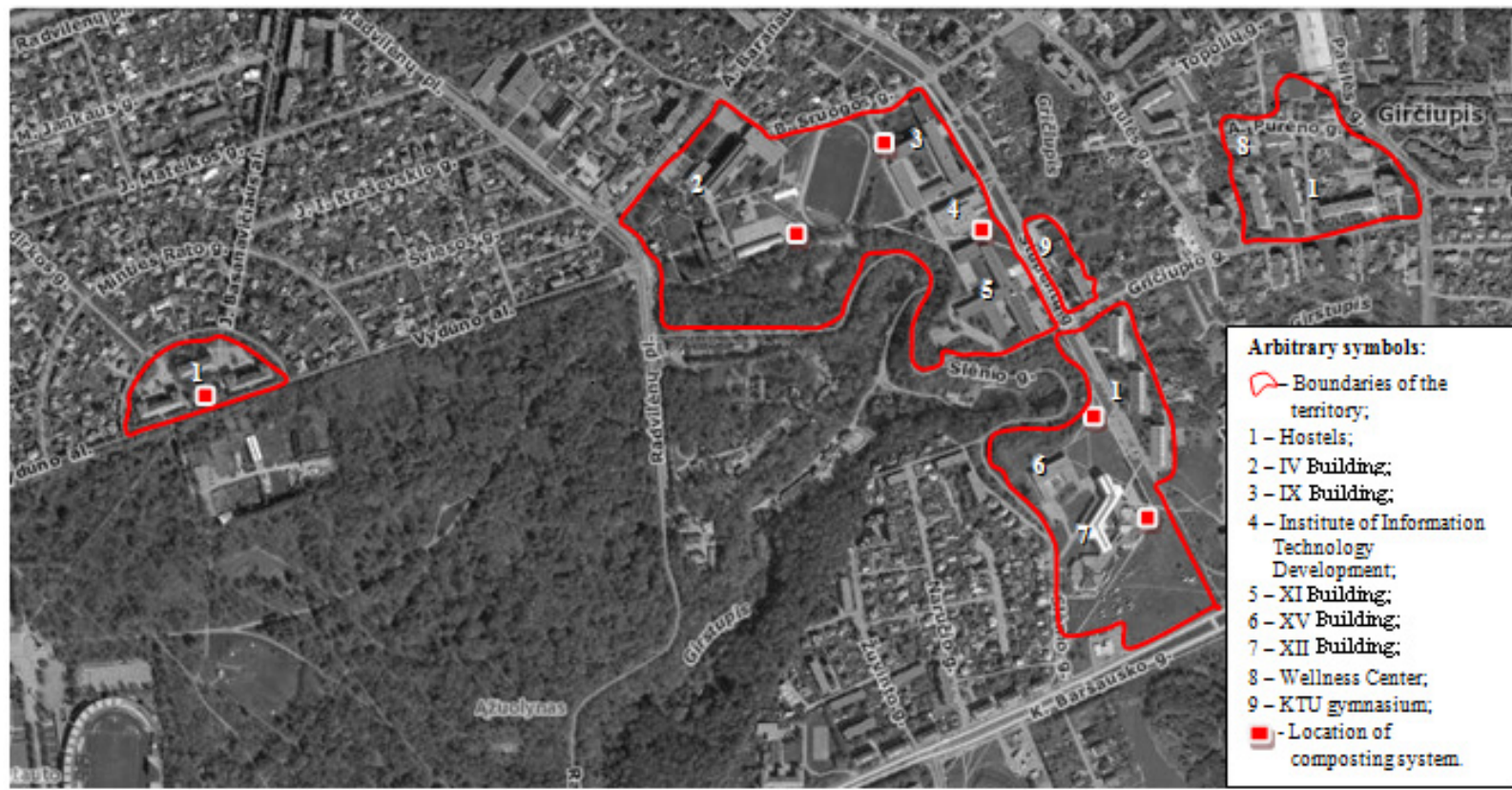

Fig. 2. Student Town area at Kaunas University of Technology (KTU) (Stanevičiūtè 2013)

Student Town is the largest KTU area of green space. All KTU canteens and a café are situated exactly in Student Town (in Buildings No. IV, IX, XI, and XII) (see Fig. 2).

Grass is a main potential for university's BDW. Grass is cut and left on the territories for mulching as a natural fertilizer every week in the season. It is evaluated that approx. $20 \mathrm{t} / \mathrm{y}$. of grass with $40-50 \%$ of moisture content is produced (see Table 6). However, grass from the stadium close to Building IV is cut and delivered to the GW composting site of Kaunas city located at about $8.5 \mathrm{~km}$ from the KTU.

Food waste as fruit and vegetable waste is other major part of KTU BDW; it makes $28 \%$ of the total amount. This waste depends on seasons, too: main part of food $\mathrm{GW}$ is produced in autumn. Unfortunately, GW from canteens and café is not sorted and it is disposed of with the MW stream.

Tree leaves make about $12 \%$ of KTU GW. Leaves are collected and directed to the GW composting site of Kaunas city.

Tree branches are not an early produced GW, because pruning works are carried out once every few years. Sometimes tree pruning work is carried out according to the agreement with the Kaunas City Municipality. Tree branches are also transported to the GW composting site of Kaunas city.

Methodology for the feasibility analysis of BDW management in KTU is proposed (see Fig. 3). This methodology has been used in evaluating the existing situation of BDW management, in determining the volume of $\mathrm{GW}$ and optimal proportion of pre-composted materials and in estimating GW composting alternatives. First of all, the experiment on determination of GW density and amount of each flow has been made in APINI, its results are presented in Table 6.
Table 6. Amount of GW produced in KTU

\begin{tabular}{|c|c|c|c|c|}
\hline No. & Type of GW & $\begin{array}{c}\text { Amount of } \\
\text { formation, } \\
t / y \text {. }\end{array}$ & $\begin{array}{c}\text { Moisture } \\
\text { content, } \\
\% \\
\end{array}$ & $\mathrm{C}: \mathrm{N}$ ratio \\
\hline 1. & Tree leaves & $\sim 5$ & $30-50$ & $30-50: 1$ \\
\hline 2. & Grass & $\sim 20$ & $40-50$ & 15-20:1 \\
\hline 3. & Tree branches & $\sim 3$ & $10-20$ & 200-300:1 \\
\hline \multirow[t]{2}{*}{4.} & $\begin{array}{l}\text { Vegetable and } \\
\text { fruit waste }\end{array}$ & $\sim 11$ & $15-35$ & 10-20:1 \\
\hline & Total: & $\sim 39$ & $29-43$ & $30-47: 1$ \\
\hline
\end{tabular}

Three sorted GW management (composting) alternatives are proposed:

- traditional composting of BDW in a KTU storehouse using turners;

- $\quad$ vermi-composting of BDW in a KTU storehouse; - open composting in a composting bins system.

In the first and second cases, the KTU storage house situated approx. $1 \mathrm{~km}$ from KTU Building XII is suggested as an alternative place for the composting process (storage area $-480 \mathrm{~m}^{2}$, height $-7.6 \mathrm{~m}$ ).

Formation of windrows (piles: $3 \times 22.8 \times 1.3 \mathrm{~m}$ ) and their periodically turning by special equipment (turner) are suggested in first alternative (Selivanovskaya et. al. 2010). The area of the composting site is $230 \mathrm{~m}^{2}$. The first composting period would take approx. 2-3 months. Therefore, it is possible to perform 3 composting cycles per year. It would be sufficient to manage the KTU green BDW. 


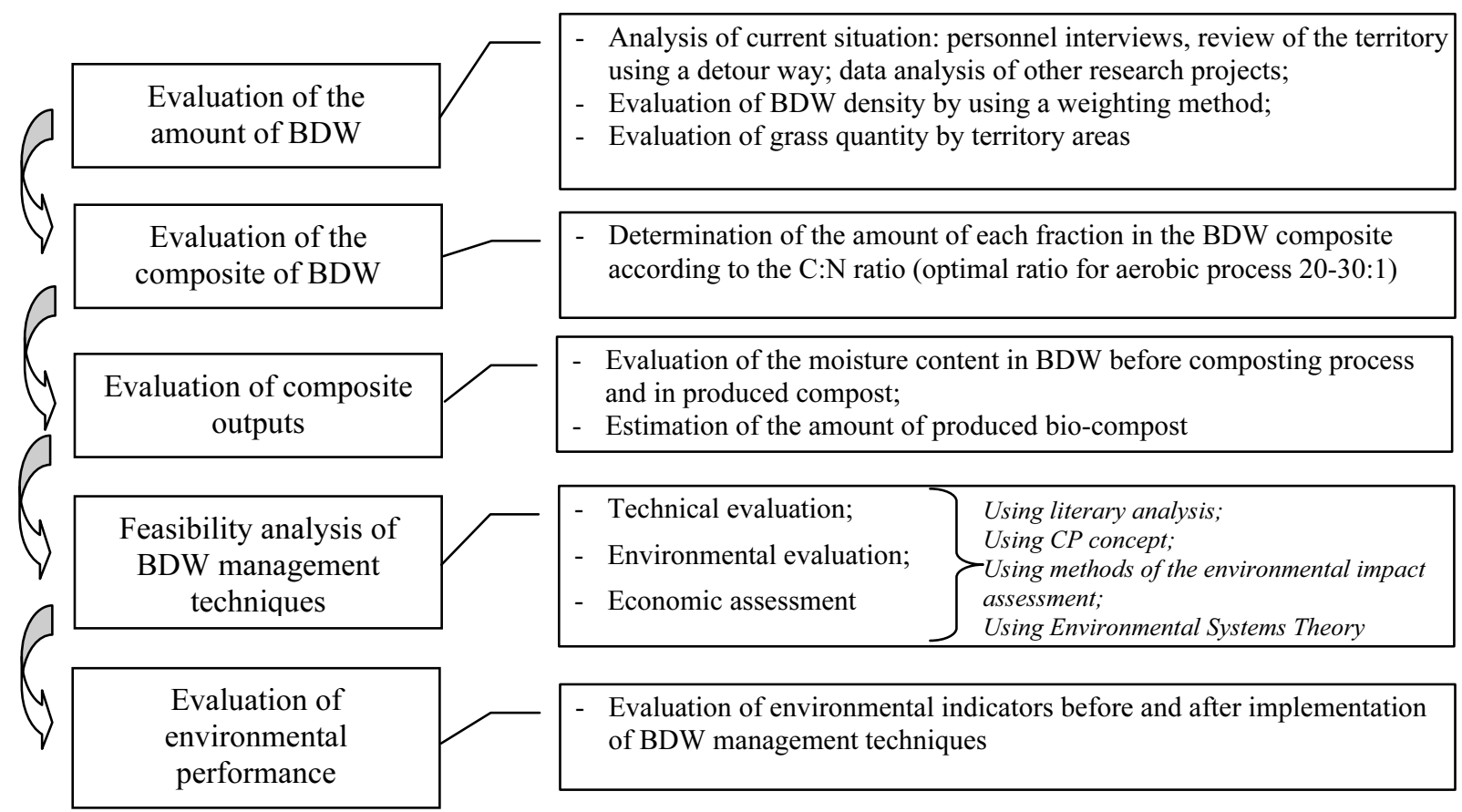

Fig. 3. Methodology for analysis of BDW composting alternatives (Stanevičiūtè 2013)

The second alternative suggests the use of earthworms in the composting process by which the vermin-compost is produced within 6-8 weeks from the start of the system installation (Albanna 2012). The composting process would be carried out in three vermin -composting systems within $195.5 \mathrm{~m}^{2}$ of the total area. Dimensions of a system: $1.5 \times 23 \times 2 \mathrm{~m}$ (working depth - $1 \mathrm{~m}$ ). Six composting cycles per year can be pe3rformed for the KTU BDW composting.

Comparison of materials and energy balances of the suggested KTU BDW composting process in windrows, by using earthworms and a system of composting bins are presented in Table 7 . Fuel has to be used for the BDW collection and delivery to the composting sites, for compost turning (in case of a first alternative). Electric power is used in a vermicomposting system (cable-winding) (in case of a second alternative). In all alternatives waste water collection and recycling are suggested. The reuse of earthworms is also planned.

Major investments of the first alternative are directed to turners and maintenance and make up approx. 185 thousand Lt. Total investment to the vermi-composting system is 169 thousand $\mathrm{Lt}$, inc. $55 \%$ of it for the purchase of earthworms $(776 \mathrm{~kg})$.

Implementation of 6 systems of BDW composting bins near the BDW production places is suggested in the third alternative: 5 systems can be situated near the Buildings in Student Town and one system - near student hostels (Vydūno av.) (see Fig. 2, No.1).Each composting system consists of three or four bins (see Fig. 4): the first BDW composting stage will be carried out in one or two semi-open bin (-s), compost maturation - in a third bin, a fourth bin with a cover will be used for produced compost storage. The number of composting bins depends on the volume and composition of BDW.

Special awning of PVC plate will protect the composting process from a direct environmental impact. The volume of each bin is $4 \mathrm{~m}^{3}$. Maximum height of a BDW pile within the bin is $1-1.5 \mathrm{~m}$. The area requisite for one composting system is $16 \mathrm{~m}^{2}$.

It is evaluated that the whole one composting cycle will last 6 months. A compost pile in the bin is filled up step by step. The layer at the bottom of a bin is composted first (after $\sim 3$ months), and then part of it is transferred to the next bin. Such pre-composted BDW transfer from one bin to another makes it possible to get oxygen to the composted pile and to optimize the composting process.

The results of economic evaluation show that implementation of the third alternative will make it possible to minimize direct costs of the BDW processing by $11 \%$ (see Table 8). The project investments (about 20 thousand Lt) are directed to building materials for the construction of composting systems and new equipment for grass collection. The pay-back period of the project is 3.5 years.

Results of the feasibility analysis of KTU BDW composting alternatives show that the composting process in the third alternative has a minimal environmental impact and the best economic effect. 
Table 7. Comparison of material / energy balances of suggested BDW managing alternatives

\begin{tabular}{|c|c|c|c|c|}
\hline \multirow{2}{*}{$\begin{array}{l}\text { Inputs and outputs of GW management } \\
\text { process }\end{array}$} & \multirow[t]{2}{*}{ Units } & \multicolumn{3}{|c|}{ Materials and energy balances of BDW composting } \\
\hline & & $\begin{array}{l}\text { in windrows, } \\
\text { units/y. }\end{array}$ & $\begin{array}{l}\text { using earthworms, } \\
\text { units/y. }\end{array}$ & $\begin{array}{l}\text { in composting bins } \\
\text { system, units/y. }\end{array}$ \\
\hline \multicolumn{5}{|l|}{ Inputs } \\
\hline BDW & $t$ & 39 & 39 & 39 \\
\hline Fuel for BDW collection & $l$ & 3801 & 3801 & 3801 \\
\hline Fuel for BDW transportation & $l$ & 108 & 108 & 22 \\
\hline Fuel for BDW processing & $l$ & 2 & - & - \\
\hline Electricity for BDW processing & $k W h$ & - & 297 & - \\
\hline Lubricant & $l$ & 0.5 & 0.5 & 0.5 \\
\hline${ }^{1}$ Water consumption (for irrigation) & $m^{3}$ & $5-16$ & $5-16$ & $5-16$ \\
\hline \multicolumn{5}{|l|}{ Outputs } \\
\hline Compost & $t$ & $22-27$ & $22-27$ & $22-27$ \\
\hline Usage for university needs & $t$ & 11 & 11 & 11 \\
\hline Bio-compost for sale & $t$ & $11-16$ & $11-16$ & $11-16$ \\
\hline Wastewater (the rest of it after recycling) & $m^{3}$ & $6-12$ & $6-12$ & $6-12$ \\
\hline Emissions from mobile sources & $t$ & 5.2 & 5.2 & 5.1 \\
\hline Emissions from BDW processing & $t$ & $4.5-5.5$ & $4.5-5.5$ & $4.5-5.5$ \\
\hline
\end{tabular}

${ }^{\text {IRecycled wastewater }}$

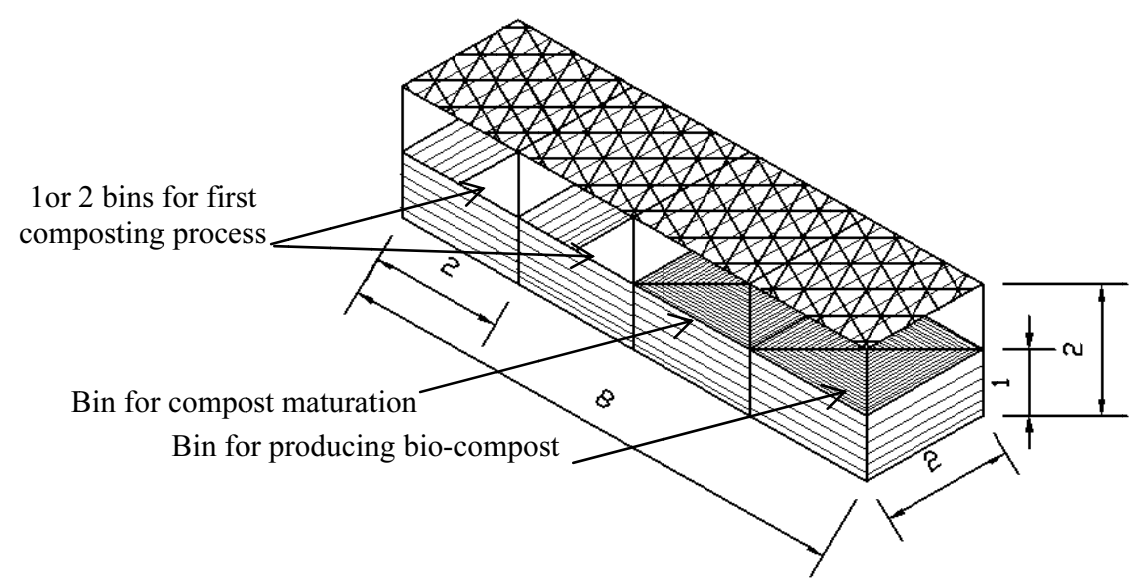

Fig. 4. System of composting bins (Stanevičiūtè 2013)

Table 8. Results of economic evaluation of a third alternative (system of composting bins)

\begin{tabular}{|c|c|c|c|c|c|c|c|}
\hline \multirow[t]{2}{*}{$\begin{array}{c}\text { Inputs and outputs of KTU BDW } \\
\text { management process }\end{array}$} & \multirow[t]{2}{*}{ Unit } & \multicolumn{2}{|c|}{$\begin{array}{l}\text { Existing situation in } \\
\text { BDW management }\end{array}$} & \multicolumn{2}{|c|}{$\begin{array}{c}\begin{array}{c}\text { After implantation of } \\
\text { alterative }\end{array} \\
\end{array}$} & \multicolumn{2}{|c|}{ Savings } \\
\hline & & units/y. & Lt/y. & units/y. & $\mathbf{L t} / \mathbf{y}$. & units/y. & $\mathbf{L t} / \mathbf{y}$. \\
\hline \multicolumn{8}{|l|}{ Inputs: } \\
\hline GW (grass, tree leaves, branches) & $t$ & 28 & - & 28 & - & 0 & - \\
\hline BDW from food waste stream & $t$ & 11 & 659 & 11 & - & 0 & 659 \\
\hline $\begin{array}{l}\text { Fuel consumption for } \mathrm{GW} \\
\text { transportation }\end{array}$ & $l$ & 130 & 588 & 22 & 101 & 107 & 487 \\
\hline Fuel consumption for GW collection & $l$ & 3801 & 17789 & 3801 & 17789 & 0 & 0 \\
\hline Lubricant & $l$ & 0.5 & 20 & 0.5 & 20 & 0 & 0 \\
\hline${ }^{1}$ Water consumption (for irrigation) & $m^{3}$ & - & - & $5-16$ & - & $-5-16$ & - \\
\hline Personnel & number & 5 & 31500 & 5 & 31500 & 0 & 0 \\
\hline Mould's consumption for sward & $t$ & 10 & 605 & - & - & 10 & 605 \\
\hline $\begin{array}{l}\text { Fertilizers' consumption for flower } \\
\text { planting }\end{array}$ & $t$ & 0.3 & 2800 & - & - & 0.3 & 2800 \\
\hline \multicolumn{8}{|l|}{ Outputs: } \\
\hline Compost & $t$ & - & - & $22-27$ & - & & - \\
\hline Usage for university needs & $t$ & & & 11 & - & & \\
\hline Bio-compost for sale & $t$ & & & $11-16$ & +1500 & $11-16$ & 1500 \\
\hline $\begin{array}{l}\text { Wastewater (the rest of it after } \\
\text { recycling) }\end{array}$ & $m^{3}$ & - & - & 6 & - & -6 & - \\
\hline Emissions from BDW processing & $t$ & - & - & $4.5-5.5$ & - & $-4.5-5.5$ & - \\
\hline Direct costs (inc. VAT): & $L t$ & & 53961 & & 47910 & & 6051 \\
\hline
\end{tabular}

\footnotetext{
${ }^{I}$ Recycled wastewater
} 


\section{Conclusions}

Evaluation of possibilities of green waste home-composting in Tauragè region states that:

- $\quad$ on average up to $3.14 \mathrm{t}$ of suitable GW can be collected and composted from 1 ha of house-hold territory;

- $\quad$ on average up to $450 \mathrm{~kg}$ of BDW per household (2-5 residents, $0.06-0.1$ ha) can be collected and composted in 1 composting season using a composting bin of 7001 capacity, and about $225 \mathrm{~kg}$ of bio-compost can be produced and used therein for domestic purposes.

During the experiment, six samples were taken of pre-composted materials (samples are taken after 3 months from the beginning of composting), chemical analysis was performed and its results were compared to the basic recommended compost quality parameters (see Table 1).

The value of primary compost in terms of amount of organic matter, total nitrogen, phosphorus and kalium was very low, low or medium (since the composting process has not been completed yet). The value of primary compost in terms of such indicators as $\mathrm{pH}, \mathrm{DM}$, water-soluble nitrogen, water-soluble phosphorus, water-soluble kalium, and $\mathrm{C}: \mathrm{N}$ ratio of primary compost was very high.

In all cases the concentration of heavy metals in pre-composted materials is significantly lower than the requirements for the I category compost (compost for agriculture).

Up to $1.5 \%$ of total nitrogen and $0.6 \%$ of total phosphorus is in dry matter of the medium value compost (Staugaitis at al. 2012). Therefore up to 1.69 $\mathrm{kg}$ of total nitrogen and $0.68 \mathrm{~kg}$ of total phosphorus are present in dry matter of $225 \mathrm{~kg}$ of produced primary compost.

Using the produced compost therein (fertilization territory: 0.06 to 0.1 ha) the total nitrogen $(\mathrm{N}): 16.9$ to $28.17 \mathrm{~kg} / \mathrm{ha}$, total phosphorus (P): 6.8 to $11.33 \mathrm{~kg} / \mathrm{ha}$ will be inserted into the soil over the years. It is 6 - 10 times less according to the total nitrogen content, and $3-5.9$ times less according to the total phosphorus content compared to the compost fertilization restrictions (annual total nitrogen $\leq 170 \mathrm{~kg} / \mathrm{ha}$, total phosphorus $\leq 40 \mathrm{~kg} / \mathrm{ha}$ )) (Staugaitis at al. 2012).

In Lithuania duration of the whole composting process using closed composting bins will be:

- $\quad$ Composting in a classical way will take up to 6-7 months (produced bio-compost will be used next spring);

- Composting with probiotics, e.g. SCD Odor Away will take up to 4.5-5 months (bio-compost can be used in autumn of the same year).

Main mistakes made during the homecomposting process (Feasibility study, Part II 2013) when allowing anaerobic conditions are:

wetting the BDW mix by watering (with buckets) instead of spraying (moisture content increases more than $60 \%$; oxygen content significantly decreases);
- $\quad$ at the beginning and/or during the composting process, no structural materials (small branches) are added, the compost is periodically mixed (oxygen content significantly decreases below $15 \%)$

- $\quad$ the composting temperature is not reached:

○ non-crushed BDW are composted (e.g. straw, flowers, etc), thus the oxygen content increases more than $20 \%$;

○ waste does not biodegrade because the main composting process parameters are not observed, e.g. only grass waste with $\mathrm{C}: \mathrm{N}$ ratio 15-20:1 is composted (lack of C-rich BDW (e.g. leaves, chopped straw, branches, etc);

○ dry BDW is composted (moisture content is less than $40 \%$, activity of microorganisms starts to decline and stops when the moisture content is less than $20 \%$ )

There are 5.8 thousand units of individual households in Taurage region towns and small towns. Home-composting of BDW in these households will allow minimizing waste disposal in landfill up to $2610 \mathrm{t} / \mathrm{y}$. Therefore, the BDW management objectives for Taurage region, scheduled in the BDW management study and MW management plan are realistic (Feasibility study on biodegradable waste 2010; Waste management plan 2010).

Feasibility analysis of possibilities of BDW management techniques in Kaunas University of Technology states that:

About $38.8 \mathrm{t} / \mathrm{y}$. of green BDW are generated in KTU, inc. $51 \%$ of grass, $28 \%$ of green food waste, $12 \%$ of tree leaves, $9 \%$ of tree branches (see Table 6).

- The existing BDW management situation: grass is mulched, tree leaves and branches are disposed of in the green waste composting site of Kaunas, while vegetable and fruit waste is disposed of in landfill with MW stream. Environmental cost of BDW management for KTU is up to 54 thousand $\mathrm{Lt} / \mathrm{y}$.

- Three alternatives of BDW composting are proposed and evaluated:

$\circ$ traditional composting of BDW in the KTU storehouse using turners;

○ vermi-composting of $\mathrm{BDW}$ in the KTU storehouse;

$\circ$ open composting in the composting bins system.

- Results of the feasibility analysis show that composting of waste near their production source is economically and environmentally the best way.

- Implementation of a third alternative in KTU will make it possible to minimize direct costs of BDW management by $11 \%$ by producing $26 \mathrm{t}$ of bio-compost with a minimum environmental impact. The pay back of the project investments is in 3.5 years. 


\section{References}

Index data base. 2013. Statistic Lithuania.

Environmental Agency. Municipal Waste Accounting. Municipal waste, 2009-2011. 2013-01-01

http://atliekos.gamta.lt

RECO Baltic-21 Tech project website http://www.recobaltic21.net/en.html

National Strategic Waste Management Plan (NSWMP) Approved by Resolution of the Government of the Republic of Lithuania (No.519, 2002; last additions 2010) (in Lithuanian).

Feasibility study. Evaluation of possibilities of biodegradable waste home-composting in Taurage region. Part I. Kliopova I. Knašytė M. Applied research work. RECO Baltic-21 Tech project. Editor - dr. Motiejūnas J.. Kaunas, 2012 (in Lithuanian)

Feasibility study. Evaluation of possibilities of biodegradable waste home composting in Taurage region. Part II. Kliopova I. Applied research work Home composting experiment. RECO Baltic-21 Tech project. Kaunas, 2013 (in Lithuanian).

Stanevičiūtė K. Feasibility analysis of biodegradable waste management techniques in Kaunas University of Technology. Master`s Work in Environmental Management and Cleaner Production. KTU APINI. Kaunas, 2013 (in Lithuanian).

Staugaitis G., Mažeika R., Antanaitis A., Antanaitis Š. Analysis and evaluation of quality requirements of compost, usable for agriculture. Applied research work. Agrochemical Laboratory of Centre of Lithuanian Agriculture and Forestry Science (LAAMMC). Kaunas, 2012 (in Lithuanian).

Feasibility study on biodegradable waste management in Tauragè region. „NPR“ Ltd., „Hidroterra“ Ltd., „EcoIri Solution“ Ltd. 2010 (in Lithuanian).

Tauragé region waste management plan for 20102020. "Ekobaltas" Ltd., "Atliekų tvarkymo konsultantai" Ltd. 2010 (in Lithuanian).

SCD Odor Away. AVAI. Institute of Environmental management and audit

http://www.avai.lt

The GORETM Cover System. A Leading Composting Technology for Organic Waste Treatment

http://www.cityofpaloalto.org
Ripley, S., Mackenzie, K. Study of Options for a Centralized Composting Pilot Project in the City of Yellowknife. 2008

Kliopova I. Feasibility study. Development of biodegradable waste management system at Palanga city municipality. Editors: assoc. prof. dr. Jolita Kruopienė. RECO Baltic-21 Tech project. Kaunas, 2012 (in Lithuanian).

Worlds weather online

$\mathrm{http} / / / \mathrm{www}$. worldweatheronline.com

Špokas L. Production of Grass Silage. My farm 2009/6 (in Lithuanian).

Smith, K. How to Build, Maintain, and Use a Compost System: Secrets and Techniques You Need to Know to Grow the Best Vegetables. Atlantic Publishing Group, Inc., 2011. P. 20-23.

Selivanovskaya, S. Yu., Karipova, S. K., Latypova, V. Z., et. al. Treatment and Disposal of Biosolids. Wang, L. K., Tay, J.-H., Tay, S. T. L., et. al. (eds.), Environmental Bioengineering, 11. Springer Science + Business media, LLC, 2010. P. 32-34.

Albanna, M. Solid Waste Management Options and their Impacts on Climate Change and Human Health. Malik, A., Grohmann, E. (eds.), Environmental Protection Strategies for Sustainable Development. Springer Science + Business Media, 2012. P. 499-528.

Dr. Irina Kliopova, Associated prof., Institute of Environmental Engineering, Kaunas University of Technology

Main research areas: Environmental Impact Assessment; Integrated Pollution Prevention and Control; Biodegradable waste management; Energy efficiency and alternative energy production

Address: Teatro str. $8-16$, Vilnius,

Tel.: $\quad$ LT-03107 Lithuania

E-mail: irina.kliopova@ktu.lt

Ms. Kamilè Stanevičiūtė, Institute of Environmental Engineering, Kaunas University of Technology

Main research areas: Cleaner Production,

Biodegradable waste management

Address: K. Donelaičio str. 20, Kaunas LT-44239 Lithuania

Tel: $\quad+370-60682795$

E-mail: k.staneviciutes@gmail.com 


\title{
Žaliụjų atliekų kompostavimo galimybių įvertinimas
}

\author{
Irina Kliopova, Kamilè Stanevičiūtè \\ Kauno technologijos universitetas, Aplinkos inžinerijos institutas, Lietuva
}

(gauta 2013 m. birželio mèn.; atiduota spaudai 2013 m. rugsëjo mèn.)

Vienas iš esminių klausimų, susijusių su biologiškai skaidžių atliekų (BSA) tvarkymu, yra šių atliekų šalinimas sąvartynuose. Aplinkos agentūros duomenimis, Lietuvoje kasmet susidaro apie 1,2-1,3 mln. t komunalinių atliekų (KA) (ịskaitant komunalines pakuotes bei padangas ir neįskaitant viešujų teritorijų žaliujų atliekų (ŽA)). Remiantis preliminariais skaičiavimais, BSA KA sraute sudaro nuo 40-50 proc. (t. y. 480-650 tūkst. t/m.). Lietuvos valstybiniame strateginiame atliekų tvarkymo plane (VSATP) nustatytas pagrindinis BSA tvarkymo siekis: iki 2020 m. sąvartynuose gali būti šalinama tik iki 35 proc. BSA 2000 m. lygio (t. y. apie 254 tūkst. t/m.). VSATP taip pat pabrèžiama, kad žaliosios atliekos (sodų, želdynu ir parku biologiškai skaidžios atliekos) turi būti surenkamos ir apdorojamos kompostavimo įrenginiuose. Privaloma skatinti ir individualiai kompostuoti žaliąsias atliekas (VSATP).

Straipsnyje daugiau dėmesio skiriama būtent žaliujjų atliekų (ŽA) (daržo, vejų, parkų, kitų viešųų teritorijų ir maisto ŽA) kompostavimui - vienam iš aplinkosauginiu ir ekonominiu požiūriu naudingesnių šių BSA tvarkymo būdų.

Straipsnyje pateikiama detalesnè informacija apie dviejų vykdomų KTU APINI projektų rezultatus:

- Namudinis kompostavimas Tauragès regiono individualiosiose valdose (,RECO Baltijos-21 Tech (RB21T)“ projektas);

- BSA tvarkymo Kauno technologijos universitete (KTU) galimybių ịvertinimas (projektas „KTU - Žaliasis universitetas“").

Baltijos jūros regiono programos finansuojamo projekto „RECO Baltijos-21 Tech“ (toliau RECO projektas) tikslas - skatinant ES direktyvų igyvendinimą ir padedant regionams tvarkyti atliekas pagal atliekų tvarkymo hierarchiją, sustiprinti vietinius ir regioninius gebejjimus integruotos atliekų vadybos srityje. Vienas iš uždavinių, vykdant RECO projektą Lietuvoje, parengti Tauragès regione individualiosiose valdose susidarančių BSA tvarkymo galimybių studiją (toliau - BSA studija) (BSA studija. I dalis 2012; BSA studija. II dalis 2013).

Tauragés regione apie 41 proc. gyventojų gyvena kaimo vietovėse. Regione susidaro apie 30 tūkst. t/m. KA, taip pat apie 50-60 proc. BSA. Todèl Tauragès regiono atliekų tvarkymo 2010$2020 \mathrm{~m}$. plane daug dėmesio skiriama atskiram BSA kompostavimui miestu ir miestelių individualiųjų namų valdose, t. y. tvarkymui susidarymo šaltinyje ir šios idejos skatinimui. BSA studijos tikslas: praktiškai ir teoriškai ịvertinti Tauragès regiono individualiose valdose susidarančių BSA tvarkymo galimybes.

Straipsnyje pateikti pagrindiniai BSA studijos rezultatai: įvertintos kompostavimo proceso sąlygos ir pateiktos rekomendacijos, kaip jas išlaikyti (žr. 3 lentelę); palygintos rinkoje siūlomos kompostavimo dèžès (konteineriai), ịvertinti jų pranašumai ir trūkumai; pateikti kompostavimo eksperimento pagrindiniai rezultatai; pateikti kompostavimo děžių atrankos kriterijai (žr. 4 lentelę).

Kompostavimo eksperimento dalyviai:

- Tauragès regiono 19 namų ịvairių valdų: 10 - miestų, 9 - kaimo vietovių (10 kompostavo BSA klasikiniu būdu, 9 - naudojo SCD Odor Away probiotikus);

- UAB „Tauragès regiono atliekų tvarkymo centras“: išdalijo eksperimentui tinkamas kompostavimo dėžes (iki 700 l), organizavimo susitikimą su gyventojais ir informacijos sklaidą;

- UAB „Ekobaltas“: eksperimento dalyviams išdalijo probiotines medžiagas SCD Odor Away ir dalyvavo eksperimente, stebint kompostavimo proceso eigą ir rezultatus;

- KTU APINI: parengè metodinę medžiagą, informavo gyventojus apie eksperimento tikslą, eigą ir kompostavimo proceso ypatumus; apdorojo duomenis ir pateikè rezultatus BSA studijoje. 
Atlikus žalụjų BSA namudinio kompostavimo Tauragès regione galimybių ịvertinimą, nustatyta:

- Nuo 1 ha teritorijos galima vidutiniškai surinkti iki 3,14 t kompostavimui tinkamų ŽA kiekio.

Vidutiniškai viename namų ūkyje (2-5 gyventojai, 0,06-0,1 ha) per 1 kompostavimo sezoną naudojant 7001 talpos uždarą kompostavimo konteinerį galima sukompostuoji iki $450 \mathrm{~kg}$ BSA ir pagaminti nuosaviems ūkio reikmėms iki $225 \mathrm{~kg}$ biokomposto.

Šešių mėginių su pirminiu kompostu (3 mèn. nuo kompostavimo pradžios) cheminès analizès rezultatai palyginti su pagrindinèmis rekomenduojamomis komposto kokybès nustatymo rodyklėmis (Staugaitis et al. 2012). Kadangi kompostavimo procesas dar nebuvo užbaigtas, tiriamas pirminis kompostas pagal organinès medžiagos (OM), suminio azoto, fosforo ir kalio kieki labai vertingas nebuvo. Pagamintas pirminis kompostas ypač vertingas pagal šiuos rodiklius: $\mathrm{pH}$, sausoji medžiaga (SM), vandenyje tirpus fosforas, azotas, kalis, C:N santykis. Visais atvejais sunkiujų metalų koncentracija mišiniuose yra gerokai mažesnè, negu pateikta komposto I kategorijos reikalavimuose (kompostas - skirtas naudoti žemės ūkyje).

- Probiotinių kompozicijų įtaka kompostavimo procesui: naudojant probiotines kompozicijas, trumpejja mezofilinè kompostavimo fazè, dèl to mažesnè nemalonių kvapų atsiradimo ịtaka, trumpèja viso kompostavimo proceso trukmé - teisingai pagal rekomendacijas naudojant probiotikus, Lietuvos sąlygomis ,žaliajị k kompostą galima pagaminti per 3-3,5 mèn.; taip visas kompostavimo procesas gali būti atliktas per vieną sezoną.

- Vertinant, kad vidutinio vertingumo komposto sausoje medžiagoje iki 1,5 proc. bendrojo azoto ir iki 0,6 proc. bendrojo fosforo (Staugaitis et al., 2012), $225 \mathrm{~kg}$ pagaminto komposto sausoje medžiagoje yra iki $1,69 \mathrm{~kg}$ bendrojo azoto ir iki $0,68 \mathrm{~kg}$ bendrojo fosforo. Naudojant pagamintą kompostą nuosavoms reikmėms (tręšiant teritorijoje, kurios plotas - 0,06$0,1 \mathrm{ha})$, ị dirvožemi per metus bus įterpiama: bendrojo azoto $(\mathrm{N})-16,9-28,17 \mathrm{~kg} / \mathrm{ha}$, bendrojo fosforo (P) - 6,8-11,33 kg/ha. Tai 6-10 kartų mažiau pagal bendrojo azoto kieki ir 3-5,9 kartų mažiau, palyginti su komposto tręšimo apribojimais (metinis bendrojo azoto kiekis $\leq 170 \mathrm{~kg} / \mathrm{ha}$, bendrojo fosforo kiekis $\leq 40 \mathrm{~kg} / \mathrm{ha}$ ) (Staugaitis et al., 2012).

- Vertinant, kad Tauragès regiono miestuose yra iki 5,8 tūkst. vnt. individualiujų namų valdų, atliekant žaliųu B̧ BSA namudinị kompostavimą, BSA būtų pateikiama mažiau (iki 2,61 tūkst. t/m.) i šalinamų KA srautą.

Kauno technologijos universitetas (KTU) siekia būti „žaliuoju universitetu“, dèl to skiriama daug dèmesio universiteto veikloje susidarančių atliekų tvarkymui. $2012 \mathrm{~m}$. pradètas igyvendinti sistemingas antrinių žaliavų (popieriaus ir kartono atliekų bei pakuotės, plastiko atliekų ir pakuotès) rūšiavimo projektas. Kad KTU žalieji veiksmai tęstųsi, buvo atliktas BSA tvarkymo KTU galimybių ìvertinimas (Stanevičiūtė 2013). Ypatingas demėsys skiriamas būtent ŽA tvarkymui. Straipsnyje pateikta metodika, kuri gali būti taikoma kitose objektuose, kurie turi žaliuosius plotus bei maitinimo įstaigas (pvz., mokslo, gydymo ịstaigos, viešbučiai ir kt.) (žr. 3 pav.). Ivertinus KTU žalųjų BSA tvarkymo galimybes, buvo gauti tokie rezultatai:

- $\quad$ KTU per metus susidaro iki 39 t žaliujų BSA, taip pat daugiau kaip 50 proc. žolès atliekų.

Esama BSA tvarkymo situacija: žole mulčiuojama, medžių lapai ir šakos išvežami ị Kauno miesto ŽA kompostavimo aikštelę, daržovių ir vaisių atliekos šalinamos kartu su KA srautu. alternatyvos:

KTU susidarančioms ir iš KA srauto išrūšiuotoms ŽA tvarkyti pasiūlytos 3

- $\quad$ BSA kompostavimas KTU priklausančiame sandèlyje, formuojant kaupus;

- $\quad$ BSA kompostavimas KTU priklausančiame sandėlyje, naudojant sliekus;

- $\quad$ BSA kompostavimas, naudojant specialiai suprojektuotą kompostavimo dèžių sistemą.

Alternatyvų ịvykdomumo analizé parodè, kad ekonominiu ir aplinkosauginiu požiūriu priimtiniausias BSA tvarkymo būdas - kompostavimo dèžių sistema, t. y. kai atliekos tvarkomos Šalia susidarymo šaltinių. Siūloma kompostuoti KTU 6 vietose: 5 vietos - prie universiteto rūmų ir padalinių, esančių Studentų miestelyje, 1 vieta - prie studentų bendrabučių (Vydūno al.). Nustatyta, kad ịdiegus alternatyvą tiesioginiai proceso kaštai sumažètų apie 11 proc. Kompostuojant per sezoną būtų pagamintas biokompostas (iki 26 t), kuris iš dalies būtų naudojamas KTU apželdinimo tikslams. 